\title{
AN ASSESSMENT OF DYNAMICS ON CROPPING PATTERN AND CROP DIVERSIFICATION IN AKOLA DISTRICT OF MAHARASHTRA
}

Received: Dec 31, 2017; Accepted: Jan 21, 2018; Published: Feb 12, 2018; Paper Id.: IJASRFEB201823

\section{INTRODUCTION}

Diversification suggests that although the changes in the sartorial composition are taking place in the accepted pattern, but the pace is slower than the several countries. The share of agriculture in the Gross Domestic Product (GDP) of the country has progressively declined, indicating that more resources in the economy are being diversified to non-agriculture sectors. The share of agriculture workforce is declining in the secondary and tertiary sectors. Diversification in agriculture is taking place in terms of move away from crop production to other agricultural activities. The more significant changes are taking place within the cropping sector. The area under commercial crop has doubled since 1960 and now being equals half of the area under food crops. (Vyas, 1996)

In present scenario developmental paradigm of agrarian economy, specifically in case of a developing country like India, diversification concept is applied to individual farmers and to different farms as well as to study regions. In the third world country like India, where man to land ratio is high enough, agricultural diversification, especially in terms of crop diversification is very much necessary (Let, 2011).

In fact, it is obvious that the greater number of crops in combination, greater will be the degree of diversification. The main advantage of the study of crop diversification regions lies in the fact that it enables to understand that impact of physical and social economic conditions on the agricultural mosaic. Moreover, it helps to 
know the contemporary competition among the crops for an area and scope for rotation and effect on double cropping, total production and per hectare productivity. Hence, the present study was undertaken in Amravati division with the following objectives.

- To examine the performance of major crops.

- To examine the changes of cropping pattern.

- To study the trend of crop diversification.

- To work out the advantageous crops in Akola district of Maharashtra.

\section{MATERIALS AND METHODS}

The present study pertains to Akola district in Amravati division of Maharashtra State. The present study was based on secondary data collected from various government publications and pertains to a period of 43 years i.e. from 1970-71 to 2013-14. For the study all the major food grain and non-food grain crops of Akola district, which occupied more than 80 percent of the gross cropped area were selected. Thus, the present study was confined to major crops with an assumption that excluded crops do not affect the cropping pattern and in turn would not vitiate main conclusions of the study. The eleven crops are selected for the present study like Rice, Wheat, Soybean, Cotton, Jowar, Bajra, Gram, Tur, Mung, Groundnut and Sugarcane.

\section{Analytical Tools}

Growth Analysis

\section{a) Exponential model}

For examining the performance of different crop growth rates of area, production, and productivity of major crops were estimated using exponential model.

$\log \mathrm{Y}=\log \mathrm{a}+\mathrm{t} \log \mathrm{b}+\mathrm{u}$

Compound Growth Rate $=(\log b)-1] \times 100$

$\mathrm{Y}=$ area, production, yield,

$\mathrm{a} \& \mathrm{~b}=$ parameters to be estimated from exponential model.

\section{b) Coefficient of variation (C.V)}

Coefficient of variation of area, production and yield were calculated by using the following formula $\frac{\text { undard deviation }}{\text { Mean }} \times 100$

\section{Crop Diversification}

a) Herfindahl index (HI)

In order to study the crop diversification Herfindahl index have been used.

$\mathrm{HI}=$ 
Where,

$\mathrm{N}=$ The total number of crops.

$\mathrm{Pi}=$ Proportion of acreage under $\mathrm{i}^{\text {th }}$ crop to total cropped area.

\section{Advantageous Crop}

In order to work out the advantageous crops, land concentration ratio in Akola district of Amravati division with comparative advantage was computed for last 10 years i.e. from 2004-05 to 2013-14. The comparative advantage was here approximated by the per hector net revenue of each crop relative to the average revenue of the remaining crops.

\section{RESULTS AND DISCUSSIONS}

\section{Growth Rates of Area, Production and Productivity of Major Crops in Akola District}

The compound growth rates of area, production and productivity of major crops for Akola district are presented in Table 1.

During period-I, the growth rate of area of wheat was increasedsignificantly by 3.06 per cent and for bajra it was declined significantly by 1.65 per cent. The growth rates of rice and jowar showed stagnancy during period-I. The growth rates of area under all the pulses were increased significantly during period-I and among pulses other pulses showed highest growth rate by 11.48 per cent. The growth rates under cotton and other oilseeds also increased significantly by 1.91 per cent and 8.16 per cent, respectively. Sugarcane and groundnut showed stagnancy in the growth rates of area during period-I. During period-II, the growth rates of area under rice and wheat declined significantly by 5.01 per cent and 7.44 per cent. On the other hand jowar and bajra showed stagnancy in the growth rate of area. The growth rates of area under all pulses were increased significantly during period-II also. The growth rates of area of sugarcane and groundnut declined significantly by 5.63 per cent and 11.70 per cent, respectively and it was stagnant in case of cotton. During period-II the growth rate of other oilseeds were increased significantly by 14.67 per cent. During period-III, the growth rates of area under all cereals crops were declined significantly except wheat which showed positive significant growth by 3.61 per cent. Among pulses gram showed a positive significant growth rate by 9.82 per cent, while rest of the crops showed stagnancy. The growth rates of area under sugarcane and groundnut were declined significantly by 4.94 per cent and 14.27 per cent. Soybean growth rate of area was increased significantly by 43.13 per cent and it was stagnant in case of cotton during period-III.

During period-IV, the growth rates of area under all cereal crops declined significantly except in wheat, which showed significant positive growth rate by 8.79 per cent. Among pulses, the growth rates area of gram and tur increased significantly by 12.25 per cent and 1.93 per cent, while mung and other pulses growth rates were declined significantly by 2.32 per cent and 19.09 per cent respectively during period-IV. The growth rates of area under sugarcane and cotton were declined significantly by 33.58 per cent and 4.84 per cent.

During period-IV the growth rates of area of soybean, groundnut and other oilseeds increased significantly by 11.97 per cent, 9.04 per cent and 11.91 per cent respectively. During overall period growth rates of the area were declined significantly in all the cereals. Among pulses the area growth rate for gram increased significantly by 4.48 per cent during the study period. The highest growth rates of grain were observed during the period-IV i.e. 12.25 per cent. The area growth rate of soybean increased significantly during the overall period with 20.02 per cent where the highest growth was 
observed in period-III with 43.13 per cent. The growth rate of other pulses, sugar cane, cotton, and groundnut were also declined significantly. The rest of the crop showed stagnancy in the growth rate of the area during overall period.

In case of production, the growth rates of all the cereals, pulses and cotton were increased significantly during period-I. The growth rate of production of other oilseeds was declined significantly by 11.07 per cent, while it was observed stagnancy in case of sugarcane and groundnut during period-I. During period II, the growth rates of production under rice and wheat declined significantly by 10.91 per cent and 4.58 per cent. On the other hand, jowar growth rate of production increased significantly by 7.05 per cent and bajra showed stagnancy. The growth rates of production under all pulses were increased significantly during period-II also. The growth rates of production of groundnut declined significantly by 12.75 per cent.

During period-II the growth rate of production sugarcane, cotton and other oilseeds were increased significantly by 29.12 per cent, 4.89 per cent and 17.87 per cent respectively. During the period - III the growth rates of production under all cereal crops were declined significantly except wheat, which showed significant positive growth rate by 4.28 per cent. Among pulses the growth rates of all crops were increased significantly except other pulses which showed stagnancy. The growth rates of production under sugarcane and groundnut were declined significantly by 5.42 per cent and 8.87 per cent. The soybean growth rate of the area was increased significantly by 47.47 per cent and it was stagnant in case of cotton during period-III. During period-IV, the growth rates of production under all cereal crops declined significantly except in wheat, which showed significant positive growth rate by 12.34 per cent. Among pulses the growth rate of production of gram increased significantly by 17.67 per cent, while tur and mung showed stagnancy. Other pulses growth rates of production were declined significantly by 11.75 per cent. The growth rate of production under sugarcane was declined significantly by 4.21 per cent. During period-IV, the growth rates of production of cotton, soybean, groundnut and other oilseeds increased significantly by 3.75 per cent, 11.33 per cent, 15.60 per cent and 13.32 per cent respectively.

During overall period, growth rates were declined significantly in all the cereals except wheat which showed stagnancy. During overall period, growth rates of production were increased significantly in gram, tur, mung, sugarcane, soybeanand other oilseeds by 7.95 per cent, 1.80 per cent, 4.29 per cent, 1.81 per cent, 20.52 per cent and 8.20 per cent respectively. During the overall period, cotton showed stagnancy in the growth rate of production. In case of productivity, the growth rates of all the cereals were increased significantly during period-I. Among pulses all crops showed increased significant growth rate except gram which showed stagnancy. The growth rates of sugarcane and cotton were also increased significantly by 3.28 per cent and 7.66 per cent during period-I. The growth rate of productivity of other oilseeds was observed stagnancy during period-I.

During period-II the growth rates of all the crops were increased significantly except rice and groundnut which were declined by 8.38 per cent and 1.28 per cent respectively. During period-III, rice showed negative significant growth rate of productivity by 26.06 per cent, while the rest of the crops showed stagnancy. Among pulses, growth rates of all crops increased significantly except gram which showed stagnancy. The growth rates of soybean, groundnut and other oilseeds were also increased significantly by 4.95 per cent, 6.03 per cent and 5.72 per cent respectively, while sugar cane and cotton showed stagnancy during the period-III. During period-IV, the growth rate of productivity of rice was declined significantly by 23.09 per cent, while wheat and bajra showed positive significant growth rate by 2.95 per cent and 2.31 per cent. The growth rate of jowar showed stagnancy during period-IV. Among pulses except tur all crops showed positive significant growth rate of productivity except tur which showed stagnancy. The growth rates of productivity of cotton and 
groundnut increased significantly by 8.72 per cent and 3.12 per cent respectively, while it was declined in the case of sugarcane by 3.03 per cent. During period-IV the growth rates of soybean and other oilseeds were observed stagnant. During the overall period, all crops showed significant growth rate of productivity except rice and sugar cane. The growth rate of rice and sugarcane were increased significantly by 14.56 per cent and 3.28 per cent during period-I and thereafter declined significantly by 6.07 per cent and 13.56 per cent during overall period. The highest productivity growth was observed in cotton by 4.17 per cent and the lowest yield growth in soybean by 0.40 per cent during overall period.

Table 1: Compound Growth Rates of Area, Production and Productivity of major Crops of Akola District

\begin{tabular}{|c|c|c|c|c|c|c|c|c|c|c|c|}
\hline \multirow[b]{2}{*}{$\begin{array}{l}\text { S. } \\
\text { No }\end{array}$} & \multirow[b]{2}{*}{ Crops } & \multicolumn{5}{|c|}{ Area(ha) } & \multicolumn{5}{|c|}{ Production (t/ha) } \\
\hline & & $\begin{array}{c}\text { Period- } \\
\text { I }\end{array}$ & $\begin{array}{l}\text { Period- } \\
\text { II }\end{array}$ & $\begin{array}{l}\text { Period- } \\
\text { III }\end{array}$ & $\begin{array}{l}\text { Period- } \\
\text { IV }\end{array}$ & Overall & $\begin{array}{l}\text { Period- } \\
\text { I }\end{array}$ & $\begin{array}{l}\text { Period- } \\
\text { II }\end{array}$ & $\begin{array}{l}\text { Period- } \\
\text { III }\end{array}$ & $\begin{array}{l}\text { Period- } \\
\text { IV }\end{array}$ & Overall \\
\hline 1 & Rice & 1.43 & $-5.01 * * *$ & $-28.54 * * *$ & $-21.25 * * *$ & $-12.61 * * *$ & $16.02 * * *$ & $-10.91 * * *$ & $-30.51 * * *$ & $-18.75 * * *$ & $-12.52 * * *$ \\
\hline 2 & Wheat & $3.06 * *$ & $-7.44 * * *$ & $3.61 * * *$ & $8.79 * * *$ & $-3.38 * * *$ & $12.12 * * *$ & $-4.58 * * *$ & $4.28 * * *$ & $12.34 * * *$ & -0.28 \\
\hline 3 & Jowar & 1.66 & 0.53 & $-8.28 * * *$ & $-9.54 * * *$ & $-5.01 * * *$ & $19.85 * * *$ & $7.05 * * *$ & $-7.08 * * *$ & $-11.03 * * *$ & $-2.51 * *$ \\
\hline 4 & Bajra & $-1.65 * * *$ & -1.28 & $-2.65 * *$ & $-16.12 * * *$ & $-6.13 * * *$ & $10.87 * * *$ & 1.34 & -0.48 & $-14.25 * * *$ & $-4.12 * * *$ \\
\hline 5 & Gram & $5.49 * * *$ & $11.57 * * *$ & $9.82 * * *$ & $12.25 * * *$ & $4.48 * * *$ & $5.87 * * *$ & $18.14 * * *$ & $7.42 * * *$ & $17.67 * * *$ & $7.95 * * *$ \\
\hline 6 & Tur & $2.89 * *$ & $6.41 * * *$ & -0.90 & $1.93^{*}$ & 0.87 & $6.15 * * *$ & $12.19 * * *$ & $7.24 * * *$ & 1.72 & $1.80^{*}$ \\
\hline 7 & Mung & $4.75 * * *$ & $10.24 * * *$ & -1.11 & $-2.32 * *$ & 1.63 & $14.27 * * *$ & $18.72 * * *$ & $2.73^{* *}$ & 0.28 & $4.29 * * *$ \\
\hline 8 & Other pulses & $11.48 * * *$ & $8.35 * * *$ & -1.35 & $-19.09 * * * *$ & $-13.25 * * *$ & $7.85 * * *$ & $21.54 * * *$ & 0.64 & $-11.75 * * *$ & $-11.81 * * *$ \\
\hline 9 & Sugarcane & -1.25 & $-5.63 * * *$ & $-4.94 * * *$ & $-33.58 * * *$ & $-3.33 * * *$ & -1.53 & $29.12 * * *$ & $-5.42 * * *$ & $-4.21 * * *$ & $1.81^{*}$ \\
\hline 10 & Cotton & $1.91 *$ & -0.21 & 0.08 & $-4.84 * * *$ & $-3.18 * * *$ & $8.03 * * *$ & $4.89 * * *$ & 0.10 & $3.75 * * *$ & 1.07 \\
\hline 11 & Soybean & - & - & $43.13 * * *$ & $11.97 * * *$ & $20.02 * * *$ & - & - & $47.47 * * *$ & $11.33 * * *$ & $20.52 * * *$ \\
\hline 12 & Ground nut & -0.08 & $-11.70 * * *$ & $-14.27 * * *$ & $9.04 * * *$ & $-9.39 * * *$ & 0.01 & $-12.75 * * *$ & $-8.87 * * *$ & $15.60 * * *$ & $-6.37 * * *$ \\
\hline 13 & Other oilseeds & $8.16 * * *$ & $14.67 * * *$ & $1.93^{*}$ & $11.91 * * *$ & $7.17 * * *$ & $-11.07 * * *$ & $17.87 * * *$ & $7.76 * * *$ & $13.32 * * *$ & $8.20 * * *$ \\
\hline
\end{tabular}

\section{Table 1 continued}

\begin{tabular}{|c|c|c|c|c|c|c|}
\hline \multirow{2}{*}{ Sr.No } & \multirow{2}{*}{ Crops } & \multicolumn{5}{|c|}{ Productivity(kg/ha) } \\
\hline & & Period-I & Period-II & Period-III & Period-IV & Overall \\
\hline 1 & Rice & $14.56 * * *$ & $-8.38 * * *$ & $-26.06 * * *$ & $-23.90 * * *$ & $-6.07 * * *$ \\
\hline 2 & Wheat & $7.49 * * *$ & $3.10 * *$ & 0.56 & $2.95 * *$ & $3.09 * * *$ \\
\hline 3 & Jowar & $11.54 * * *$ & $6.44 * * *$ & 0.86 & -1.77 & $2.70 * * *$ \\
\hline 4 & Bajra & $4.15 * * *$ & $4.28 * * *$ & -0.22 & $2.31 * *$ & $2.50 * *$ \\
\hline 5 & Gram & 0.36 & $5.88 * * *$ & 1.61 & $5.93 * * *$ & $3.31 * * *$ \\
\hline 6 & Tur & $3.17 * *$ & $5.39 * * *$ & $5.67 * * *$ & -0.33 & 0.87 \\
\hline 7 & Mung & $11.39 * * *$ & $10.46 * * *$ & $4.10 * * *$ & $2.33 * *$ & $3.22 * * *$ \\
\hline 8 & $\begin{array}{l}\text { Other } \\
\text { pulses }\end{array}$ & $5.62 * * *$ & $12.16 * * *$ & $4.60 * * *$ & $6.17 * * *$ & $2.08 * *$ \\
\hline 9 & Sugarcane & $3.28 * *$ & $32.15^{* * *}$ & 1.15 & $-3.03 * *$ & $-13.56 * * *$ \\
\hline 10 & Cotton & $7.66^{* * *}$ & $5.20 * * *$ & 1.50 & $8.72 * * *$ & $4.17 * * *$ \\
\hline 11 & Soybean & - & - & $4.95 * * *$ & -0.11 & 0.40 \\
\hline 12 & $\begin{array}{l}\text { Ground } \\
\text { nut }\end{array}$ & $-2.97 * *$ & -1.28 & $6.03 * * *$ & $3.12 * * *$ & $3.63 * * *$ \\
\hline 13 & $\begin{array}{l}\text { Other } \\
\text { oilseeds }\end{array}$ & 1.24 & $2.80 * *$ & $5.72 * * *$ & 1.60 & $5.65 * * *$ \\
\hline
\end{tabular}

Note: $* * *, * *, *$ denote statistical significance at 1,5 and 10 per cent level respectively.

Period-I (1970-71 to 1979-80); Period-II (1980-81 to 1989-90); Period-III (1990-91 to 1999-2000); Period-IV (2000-01 to 2013-14).

\section{Coefficient of Variation in Area, Production and Productivity of Major Crops in Akola District}

As per data presented in Table No: 2, that coefficient of variation of area for groundnut was highest during periodIII and overall period by 55.99 per cent and 110.56 per cent. Thus, it is clear from the study that the value of coefficient of variation of the area of groundnut in overall period was higher than other periods. The coefficient of variation of area 
during period-I and period-IV was higher in other pulses i.e. 49.46 per cent and 214.45 per cent. Thus, it is clear that the value of the coefficient of variation of the area was highest in case of other pulses. During period-II it was highest in the case of sugarcane i.e. 59.63 per cent.

The value of the coefficient of variation of production for other oilseeds was higher in overall period i.e. 126.12 per cent. During the first period the coefficient of variation of production was highest in case of gear i.e. 54.81 per cent, during the period-II, it was in sugarcane i.e. 105.25 per cent, during the period-III it was in rice i.e. 61.35 per cent and 218.12 per cent in other pulses during period-IV respectively.

Table 2: Coefficient of Variation in Area, Production and Productivity of major Crops in Akola District

\begin{tabular}{|c|c|c|c|c|c|c|c|c|c|c|c|c|c|c|c|c|}
\hline \multirow[b]{2}{*}{$\begin{array}{l}\text { Sr. } \\
\text { No }\end{array}$} & \multirow[b]{2}{*}{ Crops } & \multicolumn{5}{|c|}{ Area (ha) } & \multicolumn{5}{|c|}{ Production (t/ha) } & \multicolumn{5}{|c|}{ Productivity $(\mathrm{kg} / \mathrm{ha})$} \\
\hline & & $\begin{array}{l}\text { Period- } \\
\text { I }\end{array}$ & $\begin{array}{l}\text { Period } \\
\text {-II }\end{array}$ & $\begin{array}{l}\text { Period- } \\
\text { III }\end{array}$ & $\begin{array}{l}\text { Period- } \\
\text { IV }\end{array}$ & Overall & $\begin{array}{l}\text { Period } \\
\text { - I }\end{array}$ & $\begin{array}{c}\text { Period } \\
\text { - II }\end{array}$ & $\begin{array}{l}\text { Period } \\
\text { - III }\end{array}$ & $\begin{array}{l}\text { Period } \\
\text { - IV }\end{array}$ & $\begin{array}{c}\text { Overal } \\
1\end{array}$ & $\begin{array}{c}\text { Period } \\
\text { - I }\end{array}$ & $\begin{array}{l}\text { Period- } \\
\text { II }\end{array}$ & $\begin{array}{l}\text { Period- } \\
\text { III }\end{array}$ & $\begin{array}{l}\text { Period- } \\
\text { IV }\end{array}$ & Overall \\
\hline 1 & Rice & 5.71 & 19.97 & 49.28 & 125.85 & 75.86 & 51.38 & 49.19 & 61.35 & 74.86 & 52.82 & 47.66 & 36.70 & 43.16 & 25.56 & 42.09 \\
\hline 2 & Wheat & 15.77 & 25.36 & 24.51 & 51.79 & 55.31 & 43.18 & 20.50 & 27.56 & 87.97 & 67.01 & 32.41 & 15.52 & 16.47 & 27.97 & 47.01 \\
\hline 3 & Jowar & 19.50 & 6.41 & 25.53 & 37.91 & 53.74 & 54.81 & 41.33 & 34.56 & 44.51 & 65.84 & 69.40 & 37.92 & 20.60 & 27.71 & 43.16 \\
\hline 4 & Bajra & 23.92 & 29.28 & 14.87 & 65.98 & 62.47 & 44.97 & 40.37 & 34.12 & 68.41 & 66.22 & 31.94 & 29.12 & 30.93 & 17.54 & 38.04 \\
\hline 5 & Gram & 19.15 & 40.91 & 37.63 & 46.92 & 68.36 & 35.01 & 66.93 & 52.15 & 70.33 & 116.00 & 29.23 & 29.39 & 29.52 & 38.60 & 53.56 \\
\hline 6 & Tur & 9.63 & 24.37 & 7.69 & 11.13 & 26.79 & 29.26 & 41.56 & 1.36 & 29.16 & 43.05 & 26.04 & 20.25 & 31.87 & 25.67 & 27.47 \\
\hline 7 & Mung & 19.09 & 42.29 & 24.30 & 18.26 & 58.55 & 38.56 & 61.63 & 45.89 & 52.34 & 84.99 & 37.25 & 37.28 & 35.37 & 42.12 & 52.75 \\
\hline 8 & Other pulses & 49.46 & 26.77 & 22.06 & 214.45 & 92.54 & 54.49 & 60.28 & 42.29 & 218.12 & 122.88 & 20.56 & 39.89 & 31.19 & 41.45 & 46.72 \\
\hline 9 & Sugarcane & 21.83 & 59.63 & 39.95 & 105.32 & 91.97 & 26.93 & 105.25 & 41.22 & 107.02 & 125.26 & 12.76 & 62.77 & 5.31 & 42.04 & 114.90 \\
\hline 10 & Cotton & 19.34 & 3.64 & 8.59 & 21.04 & 40.02 & 34.88 & 35.57 & 42.18 & 31.54 & 46.76 & 34.99 & 35.05 & 39.42 & 38.90 & 63.68 \\
\hline 11 & Soybean & - & - & 98.83 & 43.58 & 82.91 & - & - & 117.37 & 57.10 & 93.46 & - & - & 21.05 & 38.13 & 32.49 \\
\hline 12 & Ground nut & 9.02 & 38.90 & 55.99 & 49.06 & 110.56 & 41.67 & 56.20 & 36.15 & 66.66 & 117.76 & 43.38 & 41.10 & 25.45 & 29.77 & 66.57 \\
\hline 13 & $\begin{array}{l}\text { Other } \\
\text { oilseeds }\end{array}$ & 23.99 & 53.53 & 32.75 & 45.02 & 88.10 & 37.91 & 65.96 & 59.05 & 63.59 & 126.12 & 42.64 & 51.47 & 32.32 & 39.31 & 73.35 \\
\hline
\end{tabular}

Note: Period-I (1970-71 to 1979-80); Period-II (1980-81 to 1989-90); Period-III (1990-91 to 1999-2000); PeriodIV (2000-01 to 2013-14).

Among the periods under study, the overall period was observed high coefficient of variation of value in terms of productivity of 114.90 per cent, 62.77 per cent during period-II and during overall period in case of sugarcane. Thus, it is clear from the study that value of coefficient of variation of productivity of sugarcane was higher than other periods. During the period-I the coefficient of variation value was highest in case of jowar i.e. 69.40 per cent, during the period-II it was highest in rice i.e. 43.16 per cent and during the period-IV it was highest in mung i.e. 42.12 per cent.

\section{Changes in Cropping Pattern in Akola District}

The changes in cropping pattern data in Akola district of Amravati division during 1970-71 to $2013-14$ are presented in Table3.

Overall data represented in table No:3 revealed that cotton and jowar have been observed as major crops of the district during 1970-71, constituting 71.8 per cent of total cropped area. Based on the observations in the span of 43 years, cropping pattern was being changed substantially in the district. The proportion of area under cotton was 41.38 per cent in the year 1970-71, had been reduced by 15.41 per cent on 2013-14. In case of jewelry, its share in the gross cropped area has fallen to the level of 4.51 per cent in 2013-14 from 30.00 per cent in 1970-71. The proportion of area under jowar decreased drastically after 1990-91.

The proportion of area under tur over gross cropped area is found constant for the period 1970-71 to 2013-14. Decreasing proportions of the area were observed in respect of wheat, groundnut and rice respectively. On the other hand, increasing proportions of the area under gram was observed. A desirable trend in the share of other pulses was observed and it has risen from 5.50 per cent to 14.46 per cent in 2013-14 from over theyear 1970-71. Soybean emerged as one of the 
major crop of the district, occupies 40.08 per cent of gross cropped area.

The percentage change over base period 1990-91 of soybean is 9168.00 per cent, which indicates an increase of acreage under this crop. The area of rice, wheat, jowar, bajra, mung, sugarcane, cotton, groundnut, other oilseeds and othercrops have been deliberately shifted to soybean. There is positive change in other cereals by 325.00 per cent, gram by 195.31 per cent,tur by 48.09 per cent by and other pulses by 111.11 per cent next to soybean over base period 1990-91. The gross cropped area has increased by 11.86 per cent over base period 1990-91.

Table 3: Changes in Cropping Pattern in Akola District (Area in “00” ha)

\begin{tabular}{|c|c|c|c|c|c|c|c|}
\hline \multirow[b]{2}{*}{ Sr. No } & \multirow[b]{2}{*}{ Crop } & \multicolumn{5}{|c|}{ Years } & \multirow{2}{*}{$\begin{array}{c}\text { Percentage } \\
\text { Change over base } \\
\text { Period }\end{array}$} \\
\hline & & 1970-71 & 1980-81 & $1990-91$ & 2000-01 & 2013-14 & \\
\hline 1 & Rice & $\begin{array}{c}81 \\
(1.00)\end{array}$ & $\begin{array}{c}78 \\
(0.86)\end{array}$ & $\begin{array}{c}70 \\
(0.67)\end{array}$ & $\begin{array}{c}20 \\
(0.18)\end{array}$ & $\begin{array}{c}0 \\
(0.00)\end{array}$ & -100 \\
\hline 2 & Wheat & $\begin{array}{c}499 \\
(6.18)\end{array}$ & $\begin{array}{c}404 \\
(4.47)\end{array}$ & $\begin{array}{c}274 \\
(2.65)\end{array}$ & $\begin{array}{c}225 \\
(2.07)\end{array}$ & $\begin{array}{c}199 \\
(1.72)\end{array}$ & -27.37 \\
\hline 3 & Jowar & $\begin{array}{c}2421 \\
(30.00)\end{array}$ & $\begin{array}{c}2365 \\
(26.21)\end{array}$ & $\begin{array}{c}2753 \\
(26.63)\end{array}$ & $\begin{array}{c}1546 \\
(14.24)\end{array}$ & $\begin{array}{c}522 \\
(4.51) \\
\end{array}$ & -81.04 \\
\hline 4 & Bajra & $\begin{array}{c}64 \\
(0.79)\end{array}$ & $\begin{array}{c}117 \\
(1.29)\end{array}$ & $\begin{array}{c}55 \\
(0.53)\end{array}$ & $\begin{array}{c}50 \\
(0.46)\end{array}$ & $\begin{array}{c}39 \\
(0.33)\end{array}$ & -29.09 \\
\hline 5 & Other cereals & $\begin{array}{c}11 \\
(0.13)\end{array}$ & $\begin{array}{c}14 \\
(0.15)\end{array}$ & $\begin{array}{c}4 \\
(0.03)\end{array}$ & $\begin{array}{c}23 \\
(0.21)\end{array}$ & $\begin{array}{c}17 \\
(0.14)\end{array}$ & 325.00 \\
\hline 6 & Gram & $\begin{array}{c}133 \\
(1.64)\end{array}$ & $\begin{array}{c}129 \\
(1.43)\end{array}$ & $\begin{array}{c}320 \\
(3.09)\end{array}$ & $\begin{array}{c}397 \\
(3.65) \\
\end{array}$ & $\begin{array}{c}945 \\
(8.17)\end{array}$ & 195.31 \\
\hline 7 & Tur & $\begin{array}{c}365 \\
(4.52)\end{array}$ & $\begin{array}{c}393 \\
(4.35)\end{array}$ & $\begin{array}{c}761 \\
(7.36)\end{array}$ & $\begin{array}{c}881 \\
(8.11)\end{array}$ & $\begin{array}{c}1127 \\
(9.74)\end{array}$ & 48.09 \\
\hline 8 & Mung & $\begin{array}{c}210 \\
(2.60)\end{array}$ & $\begin{array}{c}409 \\
(4.53)\end{array}$ & $\begin{array}{c}733 \\
(7.09)\end{array}$ & $\begin{array}{c}652 \\
(6.00)\end{array}$ & $\begin{array}{c}564 \\
(4.87)\end{array}$ & -23.06 \\
\hline 9 & Other pulses & $\begin{array}{c}444 \\
(5.50)\end{array}$ & $\begin{array}{c}571 \\
(6.33)\end{array}$ & $\begin{array}{c}792 \\
(7.66)\end{array}$ & $\begin{array}{c}1581 \\
(14.56)\end{array}$ & $\begin{array}{c}1672 \\
(14.46)\end{array}$ & 111.11 \\
\hline 10 & Sugarcane & $\begin{array}{c}5 \\
(0.06)\end{array}$ & $\begin{array}{c}4 \\
(0.04)\end{array}$ & $\begin{array}{c}27 \\
(0.26)\end{array}$ & $\begin{array}{c}34 \\
(0.31)\end{array}$ & $\begin{array}{c}0 \\
(0.00)\end{array}$ & -100.00 \\
\hline 11 & Cotton & $\begin{array}{c}3375 \\
(41.83)\end{array}$ & $\begin{array}{c}3378 \\
(37.44)\end{array}$ & $\begin{array}{c}3617 \\
(34.99)\end{array}$ & $\begin{array}{c}3335 \\
(30.71)\end{array}$ & $\begin{array}{c}1782 \\
(15.41)\end{array}$ & -50.73 \\
\hline 12 & Soybean & - & - & $\begin{array}{c}50 \\
(0.48) \\
\end{array}$ & $\begin{array}{c}1108 \\
(10.20) \\
\end{array}$ & $\begin{array}{c}4634 \\
(40.08) \\
\end{array}$ & 9168.00 \\
\hline 13 & Ground nut & $\begin{array}{c}260 \\
(3.22)\end{array}$ & $\begin{array}{c}180 \\
(1.99)\end{array}$ & $\begin{array}{c}99 \\
(0.95)\end{array}$ & $\begin{array}{c}25 \\
(0.23)\end{array}$ & $\begin{array}{c}45 \\
(0.38)\end{array}$ & -54.55 \\
\hline 14 & Other oilseeds & $\begin{array}{c}25 \\
(0.31)\end{array}$ & $\begin{array}{c}146 \\
(1.61)\end{array}$ & $\begin{array}{c}377 \\
(3.64)\end{array}$ & $\begin{array}{c}130 \\
(1.19) \\
\end{array}$ & $\begin{array}{c}16 \\
(0.13)\end{array}$ & -95.76 \\
\hline 15 & Other Crops & $\begin{array}{c}175 \\
(2.16)\end{array}$ & $\begin{array}{c}833 \\
(9.23)\end{array}$ & $\begin{array}{c}404 \\
(3.90)\end{array}$ & $\begin{array}{c}850 \\
(7.82)\end{array}$ & $(0.00)$ & -100.00 \\
\hline & Gross cropped area & $\begin{array}{c}8068 \\
(100.00)\end{array}$ & $\begin{array}{c}9021 \\
(100.00)\end{array}$ & $\begin{array}{c}10336 \\
(100.00)\end{array}$ & $\begin{array}{c}10857 \\
(100.00)\end{array}$ & $\begin{array}{c}11562 \\
(100.00)\end{array}$ & 11.86 \\
\hline
\end{tabular}

Figures in the parenthesis are percentages over gross cropped area.

Note: Base period 1990-91had taken for all the crops according to soybean cropping.

\section{Trend in Crop Diversification in Akola District}

The analysis of changes in cropping pattern indicates that diversification took place in Akola district. The level of crop diversification varied inAkola district of Amravati division because of varied agro-climatic conditions and resource endowment of the farms. 
Herfindahl index was used to measure the level of crop diversification in the present study. Table No: 4 revealed that in Akola district of Amravati division, the value of Herfindahl Index was found significantly low i.e. less than 0.5 it means in district Akola diversification took place. The diversification from subsistence crop to more commercial crops were took place in this district.

Table 4: Measurement of Crop Diversification by Herfindahl Index

\begin{tabular}{|c|c|}
\hline Year & Akola \\
\hline $1970-71$ & 0.26 \\
\hline $1980-81$ & 0.24 \\
\hline $1990-91$ & 0.18 \\
\hline $2000-01$ & 0.17 \\
\hline $2013-14$ & 0.18 \\
\hline
\end{tabular}

Note :- >0.5 - indicate - diversification

$<0.5$ - indicate - non significant

\section{Advantageous Crops}

In order to examine the benefits of diversification, land concentration ratios of Akola district of Amravati division were computed and presented in TableNo: 5.

Table 5: Land Concentration Ratios of major Crops in Akola District

\begin{tabular}{|c|c|c|c|c|c|}
\hline $\begin{array}{c}\text { S. } \\
\text { No }\end{array}$ & Year & Jowar & Cotton & Soybean & Tur \\
\hline 1 & $2004-05$ & 0.55 & 4.67 & 0.29 & 0.52 \\
\hline 2 & $2005-06$ & 0.63 & 2.72 & 0.44 & 0.86 \\
\hline 3 & $2006-07$ & 0.39 & 6.82 & 0.33 & 0.30 \\
\hline 4 & $2007-08$ & 0.43 & 4.16 & 0.64 & 0.40 \\
\hline 5 & $2008-09$ & 0.38 & 8.19 & 0.29 & 0.22 \\
\hline 6 & $2009-10$ & 0.18 & 2.48 & 1.12 & 0.84 \\
\hline 7 & $2010-11$ & 0.07 & 3.08 & 1.50 & 0.48 \\
\hline 8 & $2011-12$ & 0.27 & 5.24 & 0.93 & 0.14 \\
\hline 9 & $2012-13$ & 0.11 & 2.40 & 1.84 & 0.49 \\
\hline 10 & $2013-14$ & 0.02 & 2.02 & 2.35 & 0.53 \\
\hline
\end{tabular}

Land concentration ratios of major crops in Akola district were presented in Table 5. From the table, it is seen that, the land concentration ratio of soybean showed an increasing trend over a period of study. It means soybean is a most advantageous crop in Akola district over other selected crops, i.e. jowar, cotton and tur in Akola district in Amravati division. 


\section{Advantageous crop}

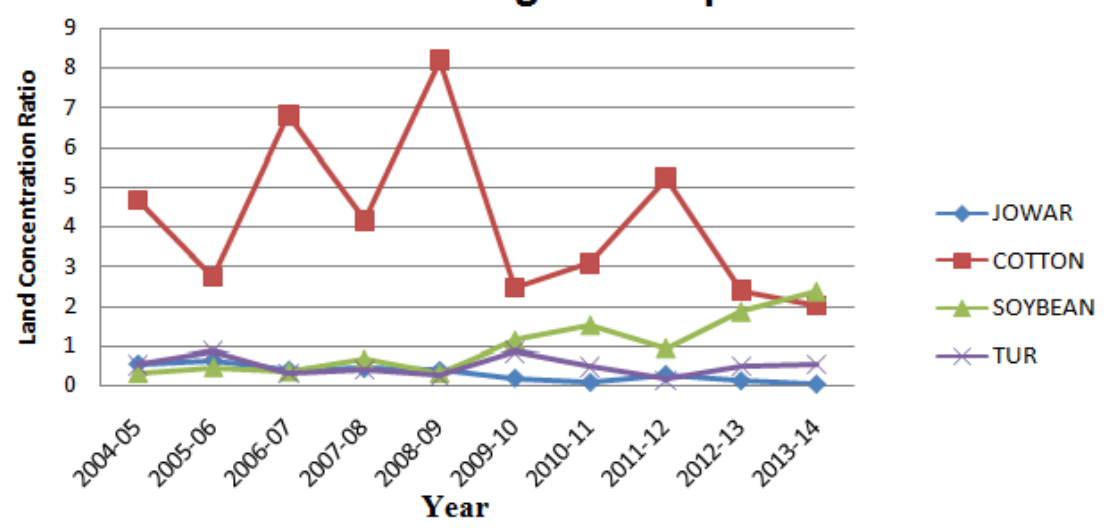

Figure 1: Land Concentration Ratios and Advantageous Crops in Akola District

\section{CONCLUSIONS}

A real growth rate of soybean was positively significant in Akola district at $1 \%$ level of significance. Soybean is more advantageous crop over jowar, cotton and tur crops in Akola. Over a period of study, cropping pattern has changed and crop diversification has increased significantly in Akola district.

\section{REFERENCES}

1. Hrideshwer Gupta.2013. Agricultural Diversification in India. International Journal Of Advanced Research in Management and Social Sciences.2(5):221-231.

2. Let, S. 2011. Crop Diversification of Birbhum District: A Spatio-Temporal Assessment, Geo-Analyst, 1(2), 23-28.

3. Tingre, A.S.,A.S. Ingole, P.D. Thakre and P.V. Shingrup.2008. Cropping Pattern Changes and crop diversification in Akola District of Vidarbha J. Soils and crops, 18(1): 240-244.

4. Vikash Pawariya et al., Impact of Ground Water Markets in Changing Cropping Pattern in Rajasthan State, International Journal of Agricultural Science and Research (IJASR), Volume 7, Issue 4, July - August 2017, pp. 103-118

5. Utpal Kumar De.2000. Diversification of crop in west Bengal : A Spatio- Temporal Analysis. Arthavijnana 42(2) : 170-182.

6. Vyas, V. S. 1996. Diversification in Agriculture: Concept, Rationale and Approaches, Indian Journal of Agril. Economics 51(4): 636-643. 
